\title{
A Meta-Analytic Review for the Patella Sexual Dimorphism Assessment
}

\author{
Una Revisión Meta-Analítica para la Evaluación del Dimorfismo Sexual de la Patela
}

\author{
Enrique Dorado-Fernández ${ }^{1,2,3}$; David Antonio Cáceres-Monllor ${ }^{1,3}$; Manuel Francisco \\ Carrillo-Rodríguez ${ }^{4}$; Bernardo Perea-Pérez ${ }^{1,3}$ \& Miguel Botella-López ${ }^{5}$
}

\begin{abstract}
DORADO-FERNÁNDEZ, E.; CÁCERES-MONLLOR, D. A.; CARRILLO-RODRÍGUEZ, M. F.; PEREA-PÉREZ, B. \& BOTELLA-LÓPEZ, M. A Meta-analytic review for the patella sexual dimorphism assessment. Int. J. Morphol., 38(4):933-939, 2020.
\end{abstract}

SUMMARY: Sexual dimorphism is one of the most important ways to identify bone remains in mass disasters. Many of them have been used for this purpose; mainly skull, pelvis and long bones. However, only a few studies using the patella have been done and, to our knowledge, there are no assessments of previous results in the literature. Meta-analysis provides a useful strong tool to test, in a systematic way, the most relevant information about a given research field. The aim of this study is to apply the meta-analytic technique to assess the major studies concerning sexual dimorphism in the patella by measuring classical metric traits: maximum height and maximum width, with different techniques, such as caliper, radiography, tomography and magnetic resonance. The 17 papers found, involving a total sample size higher than 2600 patellae, showed a very high heterogeneity- around $93 \%$ of I 2 value, for height and width measurements when all the studies were analyzed together. Homogeneity increased when each study was classified according to the techniques used. In this case, a statistical difference appeared, among the several subgroups of techniques for the two measurements, suggesting the importance of the methodology used. Maximum height and maximum width were all showed to be statistically relevant in distinguishing both sexes.

KEY WORDS: Patella; Sex; Dimorphism; Meta-analysis; Systematic review.

\section{INTRODUCTION}

Sex dimorphism is the main concern as a first step of identifying victims in mass disasters. Ethnic group and other variables could influence the assignation of the correct sex. In principle, the patella seems not to be influenced by ancestry or postmortem processes; so is a perfect bone to take into account when investigating of unknown ancestry (Introna et al., 1998).

Some studies have identified the patella as a potentially useful bone in relation to sexual dimorphism, although they show differences in mean values between males and females. Therefore, a systematic review is essential in order to collate all the empirical evidence that meets these inclusion criteria to answer some specific questions, minimize bias risk and support an objective approach to finding realistic conclusions (Antman et al., 1992; Oxman \& Guyatt, 1993).

To perform a meta-analysis in a very easy way, the Cochrane Consortium developed a software tool. Cochrane Consortium was defined as a "a global independent network of health practitioners, researchers, patient advocates and others, responding to the challenge of making the vast amounts of evidence generated through research useful for informing decisions about health" (Higgins et al., 2017).

Thus, the aim of this study was to use meta-analytic techniques to test sexual dimorphism in patella depending on several techniques of measurement supported by the most important studies found by reviewing them systematically.

\footnotetext{
${ }^{1}$ School of Clinical Forensic and Legal Medicine of Madrid, Universidad Complutense de Madrid, (Pabellón 7), Ciudad Universitaria, 28040 Madrid, España. ${ }^{2}$ Forensic Anatomical Institute of Madrid, Calle Doctor Severo Ochoa, (Pabellón 7), Ciudad Universitaria, 28040 Madrid, España.

${ }^{3}$ Department of Legal Medicine, Psychiatry and Pathology, Faculty of Medicine. Universidad Complutense de Madrid, Ciudad Universitaria, 28040 Madrid, España.

${ }^{4}$ Department of Surgery, Medical and Social Sciences, Faculty of Medicine. Universidad de Alcalá, 28871 Madrid, España.

${ }^{5}$ Laboratory of Anthropology, Faculty of Medicine. Universidad de Granada, 18016 Granada, España.
} 


\section{MATERIAL AND METHOD}

This study is part of a $\mathrm{PhD}$ dissertation which is being performed at the University of Granada (Spain), by the first author. A systematic review was performed following the PRISMA statement (Hutton et al., 2016). The next PICO questions were formulated to elucidate the problem of sexual dimorphism by means of patella measurements, following the previously published recommendations (Schardt et al., 2007):

1. Are the patella measurements, carried out using several techniques (linear-classical, 3D or CBCT models), able to statistically discriminate between genders, in a healthy adult contemporary population of any given ethnic ancestry?

The variables considered in this review were previously defined by Introna et al., as shown in Table I:

Catálogo CISNE, Web of Science and Scopus were used as searching engines to find out the most relevant bibliography in an objective way. Catálogo CISNE is a library resource provided to their researchers by the Complutense University of Madrid. The key words "patella" AND "sex" were introduced, in all of them. Figure 1 shows a summary of the systematic searches following the PICO methodology recommendations. The meta-analysis assessment and discussion were performed using the software RevMan 5.3 (Review Manager (RevMan). Two kinds of meta-analysis were performed: one based on the all results (global), and the second one, grouping them according to measurement techniques (classical or using caliper, radiography, tomography and magnetic resonance).

For any kind of explanation about meta-analysis terms, it is recommendable to read the materials and methods section published by McFadden et al., (McFadden \& Oxenham, 2018). The type of proposed data was continuous with an inverse variance random model statistical method. The effect measurement was carried out using the mean difference between males and females according to the recommendations postulated by Borenstein et al. (2010). Tables II and III show the results by total and subtotals, with a $95 \%$ C.I. for each study, and for the total C.I., indicating the number of male and female patellae analyzed on each study and on the total analysis and showing the mean difference between males and females, the standard deviation (SD), the weight of each study and their year of publication. Heterogeneity is represented by means of Tau 2 and Chi2 values, freedom degree (with the associated $\mathrm{p}$ value) and $\mathrm{I} 2$ value, while a $\mathrm{z}$ test with its associated $\mathrm{p}$ value was performed to assess the global effect heterogeneity.

Risk of bias: The authors assessed the risk bias of the studies analyzing the next items: A) JCR journal?: whether the data had been extracted from JCR indexed journals or not. B) Age between 18 to 65?: When the sample includes individuals ranging from 18 to 65 years approx. C) Modern remains/bones?: Whether the bones/remains are modern or not. D) Dried bones?: When the data concerns dried bone. E) Inclusion and exclusion criteria?: When inclusion and exclusion criteria have been stated. F) Laterality?: if the studies refer to both laterality measurements analysis or otherwise, which side left or right these measurements are performed on. G) Intra-observer analysis?: if the repeatability of the measurements has been assessed. H) Inter-observer analysis?: in case other researchers have participated in data recording. I) Same n_male than N_female?: when approximately the same number of males and females have been included in the studies (with a maximum difference of 20 allowed).

The answers to the risk bias questions were classified in the figures, according to the following color codes:

+ AFFIRMATIVE answer.

There is not enough data to answer the question.

- NEGATIVE answer.

\section{RESULTS AND DISCUSSION}

The systematic review detected 17 studies to be included in the meta-analysis: Akhlaghi et al. (2009, 2010), Bidmos et al. (2005), Dayal \& Bidmos (2005), Introna et al., Kemkes-Grottenthaler (2005), Mahfouz et al. (2007), Michiue et al. (2018), Miller et al. (1996), Abdel Moneim et al. (2008), Olateju et al. (2013), Peckmann \& Fisher (2018), Peckmann et al. (2016), Phoophalee \& Riengrojpitak (2012), Sakaue (2008), Shang et al. (2014), Yasar Teke et

Table I. Definitions of the variables.

\begin{tabular}{ccc}
\hline Variable & Abb. & Definition \\
\hline Maximal height & MH & Greatest distance between the base and the apex \\
Maximal width & MW & Greatest distance between the medial and the lateral slides \\
\hline
\end{tabular}




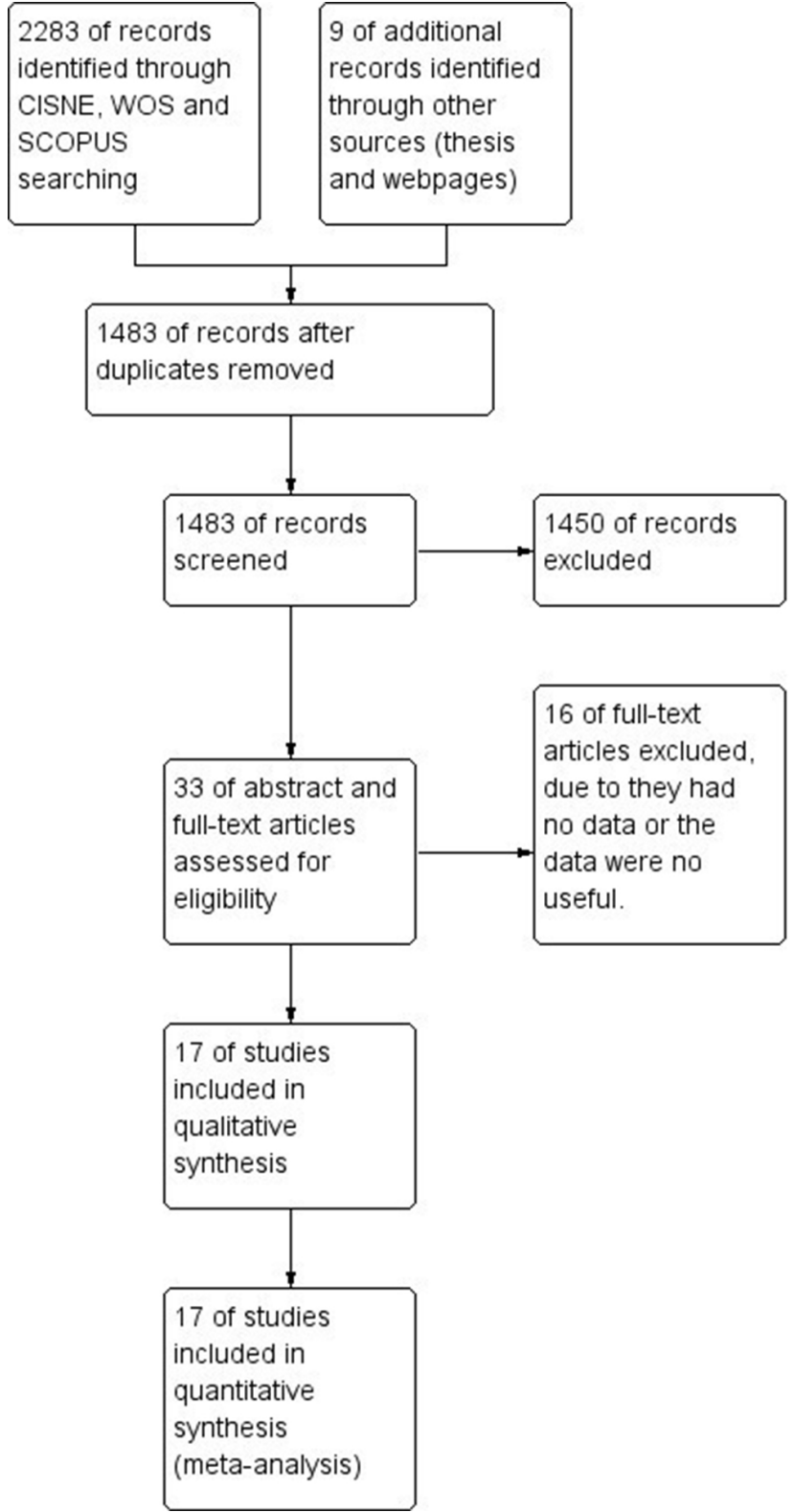

Fig. 1. Summary of the findings following a systematic review

al. (2018) and Yoo et al. (2007). The main results are showed as a summary in Tables II and III as global results and classified by techniques. The number of male and female patellae, the mean difference (range) into the mean male and mean female, tau2, Chi2, I2 and $\mathrm{z}$ are showed as well. Figure 2 shows the forest plot for the global $\mathrm{MH}$ measurement. The I2 value of $93 \%$ shows that the heterogeneity between studies is extremely high and it supposes that other variables could be relevant in the patella metrics. As it can be seen in all the figures, there are no complete standard conditions when it comes to comparing the studies. Risk bias appeared to be significant, so it is necessary to devote careful research to this. There are no studies in anthropology which take into consideration the research journals and dissertations; therefore, a new method was developed to try to solve the problem. The two most important risks observed were two: the type of population and the type of remains. Many studies were performed on fresh remains, not in dried bone, and included a mixed population with young or senescent people outside the age range of 18 to 65 . On the other hand, very few articles consider the intra or inter-observer issues, in the case of patella measurements given by different authors, must be taken with caution, especially those that have not been published in JCR journals.

Figure 3 classifies the $\mathrm{MH}$ measurement into the four most relevant techniques. There are not enough results that can be considered definitive and further searches will be needed in order to improve the meta-analysis conclusions. First, better heterogeneity can be seen in the subgroups, with a higher value approx. $59-61 \%$ for the radiography and caliper cases indicating a moderate heterogeneity. Only 2 cases were found using CT scan and 1 measured the height using MRI. The evaluation of homogeneity in both of these is not statistically relevant but, when it is studied among the 4 techniques subgroups, a statistical difference appeared ( $\mathrm{p}$ value $<0.0001)$ that would indicate that the method of measurement can influence the height of the patella, although more studies must be performed to test that conclusion. It was observed that all the measurements carried out by radiography showed a minor mean difference between males and females (Table III).

Global MW measurement is represented in Figure 4 and separated into techniques in Figure 5. This shows a heterogeneity of $94 \%$ in both cases which is high and indicates again that there were no standard conditions between studies. Only 1 study was found for the width measured with tomography. For this reason, heterogeneity value was not applicable in this case. Magnetic resonance width shows 2 studies, but Yasar Teke et al., divided the results into several age ranges concluding that age could influence the measurement. However, a very low sample size was considered into the groups.

Table II. Global meta-analysis table summary for the 3 measurements of the patella.

\begin{tabular}{ccccccccc}
\hline Variable & N males & N females & Mean Difference [Range] & Tau $^{2}$ & Chi $^{2}$ & $\mathrm{I}^{2} \%$ & df; (p) & Z; (p) \\
\hline MHG & 1325 & 1013 & $4.96[4.23 ; 5.68]$ & 1.86 & 208.71 & 93 & $15 ;<0.00001$ & $13.43 ;<0.00001$ \\
MWG & 1434 & 1123 & $5.01[4.25 ; 5.77]$ & 2.75 & 339.60 & 94 & $21 ;<0.00001$ & $12.91 ;<0.00001$ \\
\hline
\end{tabular}


Table III. Meta-analysis table summary of the patella measurements divided by techniques.

\begin{tabular}{|c|c|c|c|c|c|c|c|c|}
\hline \multicolumn{9}{|c|}{ MAXIMAL HEIGHT } \\
\hline Technique & $\mathbf{N}$ males & $\mathbf{N}$ femal es & $\begin{array}{l}\text { Mean Difference } \\
\text { [Range] }\end{array}$ & Tau2 & $\mathbf{C h i}^{2}$ & $I^{2} \%$ & df; (p) & $Z ;(p)$ \\
\hline Caliper & 679 & 512 & $5.18[4.66 ; 5.69]$ & 0.42 & 24.58 & 59 & $10 ; 0.006$ & $19.59 ;<0.00001$ \\
\hline Radiography & 334 & 305 & $3.22[2.58 ; 3.86]$ & 0.15 & 2.58 & 61 & $1 ; 0.11$ & $9.90 ;<0.00001$ \\
\hline Tomography & 170 & 170 & $5.15[4.50 ; 5.79]$ & 0.00 & 0.04 & 0 & $1 ; 0.85$ & $15.66 ;<0.00001$ \\
\hline Resonance & 142 & 40 & $5.60[4.66 ; 6.54]$ & - & - & - & - & $11.62 ;<0.00001$ \\
\hline TOTAL & 1325 & 1027 & $4.97[4.24 ; 5.70]$ & 1.89 & 216.18 & 93 & $15 ;<0.00001$ & $13.36 ;<0.00001$ \\
\hline Subgroups & - & - & - & - & 29.26 & 89.7 & $3 ; 0.00001$ & - \\
\hline \multicolumn{9}{|c|}{ MAXIMAL WIDTH } \\
\hline Caliper & 679 & 512 & $4.92[4.50 ; 5.34]$ & 0.15 & 14.65 & 32 & $10 ; 0.15$ & $23.05 ;<0.00001$ \\
\hline Radiography & 334 & 305 & $3.25[2.14 ; 4.37]$ & 0.53 & 4.44 & 77 & $1 ; 0.04$ & $5.71 ;<0.00001$ \\
\hline Tomography & 60 & 60 & $5.44[4.43 ; 6.45]$ & - & - & - & - & $10.60 ;<0.00001$ \\
\hline Resonance & 361 & 246 & $5.59[4.78 ; 6.40]$ & 0.61 & 14.15 & 51 & $7 ; 0.05$ & $13.58 ;<0.00001$ \\
\hline TOTAL & 1434 & 1123 & $5.01[4.25 ; 5.77]$ & 2.75 & 339.60 & 94 & $21 ;<0.00001$ & $12.91 ;<0.00001$ \\
\hline Subgroups & - & - & - & - & 12.20 & 75.4 & 3; 0.007 & - \\
\hline
\end{tabular}

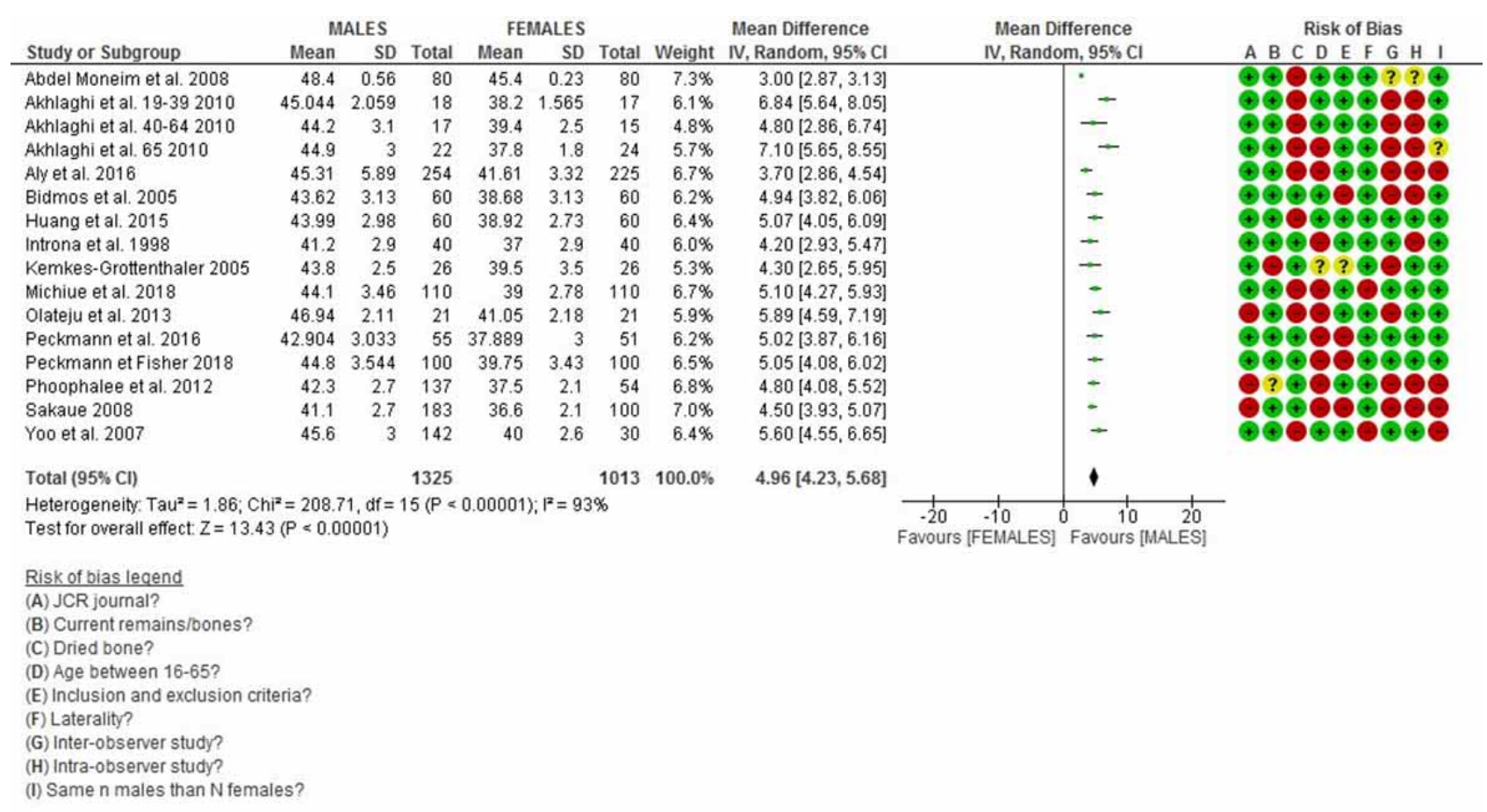

Fig. 2. Forest plot for the global MH measurement. A statistically mean difference between both sexes was found ( $\mathrm{p}$ value $<0.00001)$ for a C.I. of $95 \%$.

Taphonomic processes are non-significant in modern patella remains or are very difficult to measure. Studies included in meta-analysis do not take into account the actual taphonomic processes in the patella. Therefore, a thorough discussion about it cannot be carried out.
MGH: Maximal Height Global, the maximal height of the patella taking into account all the studies; MWG: Maximal Width Global, the maximal widht of the patella taking into account all the results; Mean Difference [Range]: range in the mean difference between the mean males and the mean females. Results are in $\mathrm{mm}$; df; (p): degree of freedom and p-value with a C.I. of $95 \%$. 


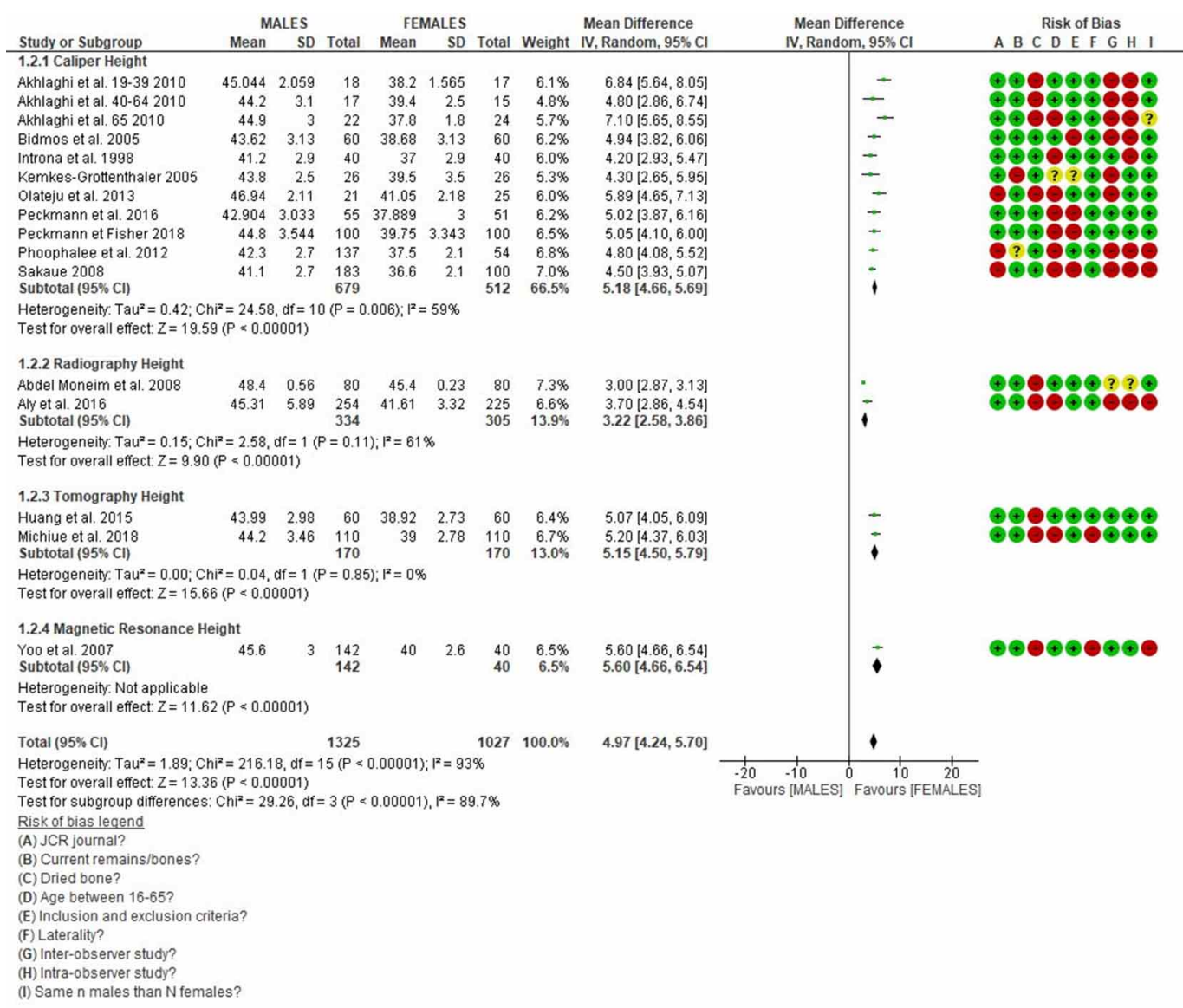

Fig. 3. Forest plot for the MH measurement divided by techniques. Statistically mean differences between subgroups can be observed (p-value $<0.00001)$ for a C.I. of $95 \%$.

\begin{tabular}{|c|c|c|c|c|c|c|c|c|c|c|c|}
\hline \multirow[b]{2}{*}{ Study or Subgroup } & \multicolumn{3}{|c|}{ MALES } & \multicolumn{3}{|c|}{ FEMALES } & \multirow[b]{2}{*}{ Weight } & \multirow{2}{*}{$\begin{array}{l}\text { Mean Difference } \\
\text { IV, Random, } 95 \% \mathrm{Cl}\end{array}$} & \multirow{2}{*}{\multicolumn{2}{|c|}{$\begin{array}{c}\text { Mean Difference } \\
\text { IV, Random, } 95 \% \mathrm{Cl}\end{array}$}} & \multirow{3}{*}{$\begin{array}{c}\text { Risk of Bias } \\
\text { A B C DE F G H I }\end{array}$} \\
\hline & Mean & SD & Total & Mean & SD & Total & & & & & \\
\hline Abdel Moneim et al. 2008 & 38.6 & 0.02 & 80 & 35.8 & 0.02 & 80 & $5.5 \%$ & $2.80[2.79,2.81]$ & & . & \\
\hline Akhlaghi et al. $19-392010$ & 46.1 & 1.8 & 18 & 39.6 & 1.8 & 17 & $4.8 \%$ & $6.50[5.31,7.69]$ & & - & $(4)$ \\
\hline Akhlaghi et al. $40-642010$ & 45.9 & 2.6 & 17 & 41 & 1.7 & 15 & $4.5 \%$ & $4.90[3.39,6.41]$ & & - & \\
\hline Akhlaghi et al. 652010 & 44.7 & 2 & 22 & 39.9 & 2 & 24 & $4.9 \%$ & $4.80[3.64,5.96]$ & & - & 0 \\
\hline Aly et al. 2016 & 48.26 & 7.48 & 254 & 44.29 & 4.459 & 225 & $4.9 \%$ & $3.97[2.88,5.06]$ & & - & \\
\hline Bidmos et al. 2005 & 45.3 & 3.26 & 60 & 40.33 & 3.28 & 60 & $4.8 \%$ & $4.97[3.80,6.14]$ & & - & 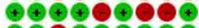 \\
\hline Huang et al. 2015 & 46.85 & 2.79 & 60 & 41.41 & 2.83 & 60 & $5.0 \%$ & $5.44[4.43,6.45]$ & & - & $(\oplus$ \\
\hline Introna et al. 1998 & 43.2 & 2.7 & 40 & 39.4 & 3.2 & 40 & $4.7 \%$ & $3.80[2.50,5.10]$ & & - & $(\odot$ \\
\hline Kemkes-Grottenthaler 2005 & 45.9 & 3.6 & 26 & 39.8 & 4.4 & 26 & $3.8 \%$ & $6.10[3.91,8.29]$ & & - & ๑) \\
\hline Olateju et al. 2013 & 48.03 & 3.41 & 21 & 42.71 & 2.52 & 25 & $4.2 \%$ & $5.32[3.56,7.08]$ & & - & \\
\hline Peckmann et al. 2016 & 44.624 & 3.28 & 55 & 40.296 & 2.942 & 51 & $4.8 \%$ & $4.33[3.14,5.51]$ & & - & \\
\hline Peckmann et Fisher 2018 & 45.01 & 3.783 & 100 & 39.79 & 3.328 & 100 & $5.0 \%$ & $5.22[4.23,6.21]$ & & - & \\
\hline Phoophalee et al. 2012 & 44.5 & 2.8 & 137 & 39.5 & 2.6 & 54 & $5.1 \%$ & $5.00[4.16,5.84]$ & & - & \\
\hline Sakaue 2008 & 43.5 & 3 & 183 & 39.1 & 2.5 & 100 & $5.3 \%$ & $4.40[3.75,5.05]$ & & - & \\
\hline Teke et al. 202018 & 45.2 & 2.68 & 4 & 43.25 & 0.07 & 2 & $3.3 \%$ & $1.95[-0.68,4.58]$ & & - & \\
\hline Teke et al. $21-302018$ & 46.7 & 3.21 & 19 & 39.41 & 3.05 & 18 & $3.9 \%$ & $7.29[5.27,9.31]$ & & $\rightarrow$ & 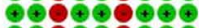 \\
\hline Teke et al. 31-40 2018 & 46.35 & 2.73 & 29 & 39.98 & 3.34 & 20 & $4.2 \%$ & $6.37[4.60,8.14]$ & & $\rightarrow$ & \\
\hline Teke et al. $41-502018$ & 46.56 & 3.16 & 30 & 40.52 & 2.91 & 41 & $4.6 \%$ & $6.04[4.60,7.48]$ & & - & $(\oplus$ \\
\hline Teke et al. $51-602018$ & 46.02 & 3.25 & 22 & 40.28 & 2.76 & 21 & $4.2 \%$ & $5.74[3.94,7.54]$ & & - & $(4)$ \\
\hline Teke et al. $61-702018$ & 46.72 & 3.13 & 5 & 42.5 & 2.58 & 4 & $2.4 \%$ & $4.22[0.49,7.95]$ & & & \\
\hline Teke et al. TOTAL 2018 & 46.34 & 3.02 & 110 & 40.35 & 2.97 & 110 & $5.2 \%$ & $5.99[5.20,6.78]$ & & - & \\
\hline Yoo et al. 2007 & 46.6 & 3.1 & 142 & 41.7 & 2.7 & 30 & $4.9 \%$ & $4.90[3.81,5.99]$ & & - & \\
\hline \multirow{2}{*}{\multicolumn{7}{|c|}{$\begin{array}{l}\text { Total }(95 \% \mathrm{Cl}) \quad 1434 \quad 1123 \\
\text { Heterogeneity Tau }=2.75 ; \mathrm{Chi}^{2}=339.60, \text { df }=21(\mathrm{P}<0.00001) ; \mathrm{F}^{2}=94 \% \\
\text { Test for overall effect } Z=12.91(P<0.00001)\end{array}$}} & $100.0 \%$ & $5.01[4.25,5.77]$ & & - & \\
\hline & & & & & & & & & 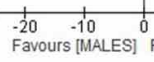 & $\begin{array}{ccc} & 1 & 1 \\
0 & 10 & 20 \\
\text { Favours [FEMALES] }\end{array}$ & \\
\hline \multicolumn{12}{|l|}{ Risk of bias legend } \\
\hline \multicolumn{12}{|l|}{ (A) JCR journal? } \\
\hline \multirow{2}{*}{\multicolumn{12}{|c|}{$\begin{array}{l}\text { (B) Current remains/bones? } \\
\text { (C) Dried bone? }\end{array}$}} \\
\hline & & & & & & & & & & & \\
\hline \multicolumn{12}{|l|}{ (D) Age between 16-65? } \\
\hline \multicolumn{12}{|c|}{ (E) Inclusion and exclusion criteria? } \\
\hline \multirow{2}{*}{\multicolumn{12}{|c|}{$\begin{array}{l}\text { (F) Laterality? } \\
\text { (G) It }\end{array}$}} \\
\hline \multirow{2}{*}{\multicolumn{12}{|c|}{$\begin{array}{l}\text { (G) Inter-observer study? } \\
\text { (H) Intra-observer study? }\end{array}$}} \\
\hline & & & & & & & & & & & \\
\hline
\end{tabular}

Fig. 4. Forest plot for the global MW measurement. A statistically mean difference between both sexes was found ( $\mathrm{p}$ value $<0.00001$ ) for a C.I. of $95 \%$. 


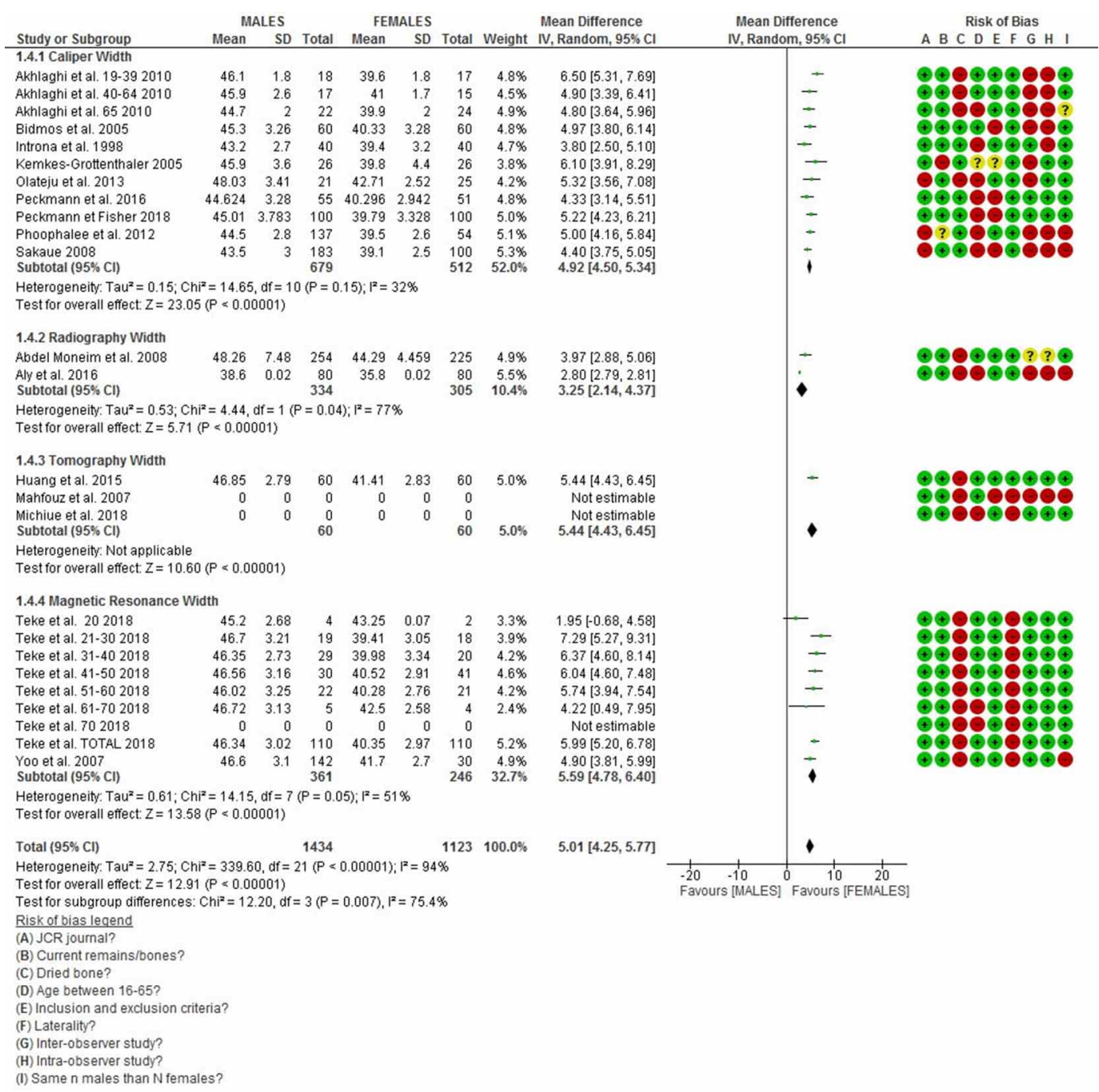

Fig. 5. Forest plot for the MW measurement divided by techniques. Statistically mean differences between subgroups can be observed (p-value $=0.007$ ) for a C.I. of $95 \%$.

\section{CONCLUSION}

In this paper the patella height, width and thickness were successfully analyzed by means of a new systematic and meta-analysis approximation. Meta-analysis is useful in the anthropology field, allowing a new tool to manage related bibliography in an objective way and supply a better understanding of the most accurate measurement. In all the patella measurements cases, statistically significant differences between males and females were found globally. When the different studies were separated according to their techniques, more differences were found comparing each subgroup. Thus, the patella measurement techniques could influence the results and hence, more thorough investigations must be performed. In addition, the moderate-high heterogeneity showed a disparity in radiography values for height and width, indicating the importance of normalizing the patella measurement methods in order to perform better analysis and achieve more realistic conclusions.

\section{DORADO-FERNÁNDEZ, E.; CÁCERES-MONLLOR, D.A.;} CARRILLO-RODRÍGUEZ, M. F.; PEREA-PÉREZ, B. \& BOTELLA-LÓPEZ, M. Una revisión meta-analítica para la evaluación del dimorfismo sexual de la rótula. Int. J. Morphol., 38(4):933-939, 2020.

RESUMEN: El dimorfismo sexual es una de las formas más importantes para identificar restos óseos en desastres masivos. Se han utilizado huesos como cráneo, pelvis y huesos largos para la diferenciación sexual. Sin embargo, solo se han realizado 
unos pocos estudios con la patela y, hasta donde sabemos, no hay evaluaciones de resultados anteriores en la literatura. El meta-análisis proporciona una herramienta sólida y útil para probar, de manera sistemática, la información más relevante sobre un cierto campo de investigación. El objetivo de este estudio consiste en aplicar la técnica metaanalítica para evaluar los principales estudios sobre dimorfismo sexual en la patela midiendo los rasgos métricos clásicos: altura máxima y anchura máxima, con diferentes técnicas: calibre, radiografía, tomografía y resonancia magnética. Los 17 de documentos encontrados, con un tamaño de muestra total superior a 2600 patelas, mostraron una heterogeneidad muy alta, alrededor del $93 \%$ del valor de I2, para mediciones de altura y anchura cuando todos los estudios se analizaron juntos. La homogeneidad aumentó cuando cada estudio se clasificó de acuerdo con las técnicas utilizadas. En este caso, se observó diferencias estadísticas, entre los subgrupos de técnicas para las dos mediciones, lo que sugiere la importancia de la metodología utilizada. La altura máxima y la anchura máxima mostraron ser estadísticamente relevantes para distinguir ambos sexos.

PALABRAS ClAVE: Patela; Sexo; Dimorfismo; Metanálisis; Revisión sistemática.

\section{REFERENCES}

Abdel Moneim, W. M.; Abdel Hady, R. H.; Abdel Maaboud, R. M.; Fathy, H. M. \& Hamed, A. M. Identification of sex depending on radiological examination of foot and patella. Am. J. Forensic Med. Pathol., 29(2):136-40, 2008.

Akhlaghi, M.; Dorooshy, G.; Naghsh, A. \& Karbakhsh Davari, M. Sex determination using patella metrical measurements: Iranian cadavers. Tehran Univ. Med. J., 67(3):190-5, 2009.

Akhlaghi, M.; Sheikhazadi, A.; Naghsh, A. \& Dorvashi, G. Identification of sex in Iranian population using patella dimensions. J. Forensic Leg. Med., 17(3):150-5, 2010.

Antman, E. M.; Lau, J.; Kupelnick, B.; Mosteller, F. \& Chalmers, T. C. A comparison of results of meta-analyses of randomized control trials and recommendations of clinical experts. Treatments for myocardial infarction. JAMA, 268(2):240-8, 1992.

Bidmos, M. A.; Steinberg, N. \& Kuykendall, K. L. Patella measurements of South African whites as sex assessors. Homo, 56(1):69-74, 2005.

Borenstein, M.; Hedges, L. V.; Higgins, J. P. \& Rothstein, H. R. A basic introduction to fixed-effect and random-effects models for meta-analysis. Res. Synth. Methods, 1(2):97-111, 2010.

Dayal, M. R. \& Bidmos, M. A. Discriminating sex in South African blacks using patella dimensions. J. Forensic Sci., 50(6):1294-7, 2005.

Higgins, J. P. T.; Chandler, J. \& Cumpston, M. S. Handbook for Systematic Reviews of Interventions version 5.2.0. London, Cochrane, 2017.

Hutton, B.; Catalá-López, F. \& Moher, D. The PRISMA statement extension for systematic reviews incorporating network metaanalysis: PRISMA-NMA. Med. Clin. (Barc.), 147(6):262-6, 2016.

Introna, F. Jr.; Di Vella, G. \& Campobasso, C. P. Sex determination by discriminant analysis of patella measurements. Forensic Sci. Int., 95(1):39-45, 1998.

Kemkes-Grottenthaler, A. Sex determination by discriminant analysis: an evaluation of the reliability of patella measurements. Forensic Sci. Int., 147(2-3):129-33, 2005.
Mahfouz, M.; Badawi, A.; Merkl, B.; Fatah, E. E.; Pritchard, E.; Kesler, K.; Moore, M.; Jantz, R. \& Jantz, L. Patella sex determination by 3D statistical shape models and nonlinear classifiers. Forensic Sci. Int., 173(2-3):161-70, 2007.

McFadden, C. \& Oxenham, M. F. Sex, parity, and scars: a meta-analytic review. J. Forensic Sci., 63(1):201-6, 2018.

Michiue, T.; Hishmat, A. M.; Oritani, S.; Miyamoto, K.; Amin, M. F.; Ishikawa, T. \& Maeda, H. Virtual computed tomography morphometry of the patella for estimation of sex using postmortem Japanese adult data in forensic identification. Forensic Sci. Int., 285:206.e1-206.e6, 2018.

Miller, T. T.; Staron, R. B. \& Feldman, F. Patellar height on sagittal MR imaging of the knee. AJR Am. J. Roentgenol., 167(2):339-41, 1996.

Olateju, O. I.; Philander, I. \& Bidmos, M. A. Morphometric analysis of the patella and patellar ligament of South Africans of European ancestry. S. Afr. J. Sci., 109(9-10), 2013. Available from: https:// www.sajs.co.za/article/view/4002

Oxman, A. D. \& Guyatt, G. H. The science of reviewing research. Ann. N. Y. Acad. Sci., 703:125-33, 1993.

Peckmann, T. R. \& Fisher, B. Sex estimation from the patella in an African American population. J. Forensic Legal Med., 54:1-7, 2018.

Peckmann, T. R.; Meek, S.; Dilkie, N. \& Rozendaal, A. Determination of sex from the patella in a contemporary Spanish population. $J$. Forensic Legal Med., 44:84-91, 2016.

Phoophalee, S. P. \& Riengrojpitak, S. Sex determination by patella measurements in Thais. Chiang Mai, GRC 2012. 1st Asean Plus Three Graduate Research Congress, 2012. pp.6.

Sakaue, K. New method for diagnosis of the sex and age-at-death of an adult human skeleton from the patella. Bull. Natl. Mus. Nat. Sci. Ser. D, 34:43-51, 2008.

Schardt, C.; Adams, M. B.; Owens, T.; Keitz, S. \& Fontelo, P. Utilization of the PICO framework to improve searching PubMed for clinical questions. BMC Med. Inform. Decis. Mak., 7:16, 2007.

Shang, P.; Zhang, L.; Hou, Z.; Bai, X.; Ye, X.; Xu, Z. \& Huang, X. Morphometric measurement of the patella on 3D model reconstructed from CT scan images for the southern Chinese population. Chin. Med. J. (Engl.), 127(1):96-101, 2014.

Yasar Teke, H.; Ünlütürk, Ö.; Günaydin, E.; Duran, S. \& Özsoy, S. Determining gender by taking measurements from magnetic resonance images of the patella. J. Forensic Leg. Med., 58:87-92, 2018.

Yoo, J. H.; Yi, S. R. \& Kim, J. H. The geometry of patella and patellar tendon measured on knee MRI. Surg. Radiol. Anat., 29(8):623-8, 2007.

\section{Corresponding author:}

David Antonio Cáceres Monllor

School of Clinical Forensic and Legal Medicine of Madrid Universidad Complutense de Madrid (Pabellón 7)

Ciudad Universitaria 28040

Madrid

ESPAÑA

\section{Email: davidcaceres77@yahoo.es enriqdor@gmail.com}

Received: 05-02-2020

Accepted: 16-03-2020 